\title{
TRANSCENDING NATIONAL POETICS A New Reading of José Lezama Lima
}

The first view of Havana immediately impresses upon a traveler the multilayered reality of Cuba. The multiplicity of political signs, whether they be the old pictures of Che Guevara or the newer billboards alluding to the forty years of the Revolution, are iconographic of Cuban reality, because in spite of their willingness to convey a message, Cubans disguise much more than they reveal. The visitor, no matter how informed beforehand about the intricacies of Cuban life, would very soon need to test and probably change his or her assumptions against what he or she sees and hears on Cuban news, from customers in coffee shops, in grocery stores, and through conversations with friends and intellectuals - some of whom are dedicated enough to read and think about the work of José Lezama Lima, by far one of the most complex figures of twentieth-century Cuban literature.

One of these assumptions is a certain didactic simplification of Lezama Lima as a one-dimensional figure: as the representative of the Revolution or its enemy; as the epic founder of a truly cosmopolitan literary magazine, Orígenes, or as the asthmatic patient who would stay home for long periods of his life and who almost never 
left the island or, after a certain point in his life, even his home. (Among the many photos of Lezama there is only one by now very rare set of pictures of him walking around Havana's Cathedral.) The complexity of his circumstances matches well the historical changes undergone by his country and ultimately by his poetics. It is this complexity, which Lezama himself refers to as "difficulty," that makes Lezama's work unique in an introspective sense and that also provides an opportunity to reflect on the extraordinary historical times in which it developed. Therefore we should look for the keys to his poetics not only in the texts themselves but also in their cultural settings and in Cuban society at large, so alive both before and after the Revolution.

In the opening statement of La expresión americana (1957), one of Lezama Lima's best-known books, the author declares: "Only difficulty is stimulating," a statement that has become Lezama's trademark, the departure point from which we are to approach his work in particular and, presumably, literature as a whole. The fact that, since Lezama's first exposure to a large Latin American readership in the late 1960 , his work has always been seen as difficult never constituted a real obstacle but rather an incentive for continuing to delve into it, based on an understanding that the complexity of his writing reflected his equally complex cosmogony. Lezama's poetic unveiling of reality is echoed in the complexities of the language itself. To recognize this serves as an effective strategy for questioning the cultural circumstances in which he was embedded without reducing them.

José Lezama Lima was born in Cuba on December i9, 19 1o, and with the exception of brief trips to Mexico in 1949 and to Jamaica in I950, he spent most of his life in Havana, where he died in 1976 . Yet his writing always went beyond the cultural boundaries of his nation. Lezama's private and public personas were barely separate, and many 
of his activities as publisher and cultural broker were marked by a noninstitutional, almost domestic, character. After the premature death of his father, when Lezama was only nine years old, he and his mother moved into his grandmother's house on Calle Prado and later to 162 Trocadero Street, where the writer lived until his death. His father's death left the family in a precarious situation from which the family never completely recovered. In spite of his family's financial difficulties and his own severe asthmatic condition, Lezama was able to establish around his home an expanding artistic circle of painters, musicians, and writers, which would become a defining factor of Cuba's twentieth-century cultural life. Lezama's work, his poetry,

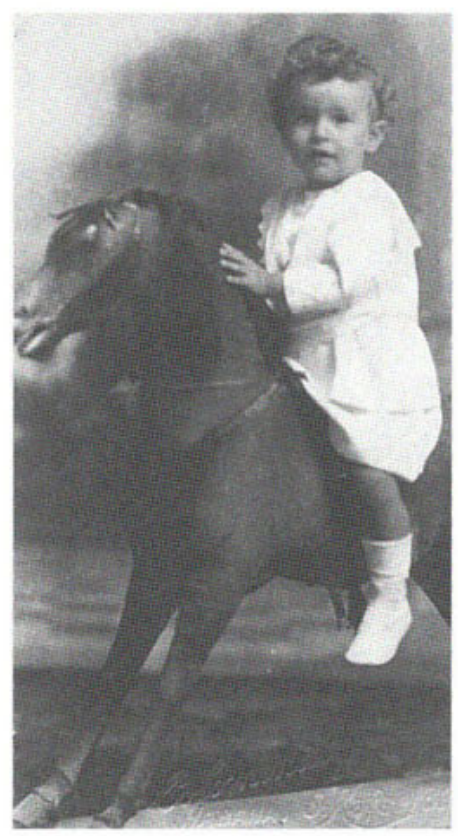

Lezama Lima at a year and nine months old, 1912. novels, and essays, are the result of the social and personal circumstances in which he developed his poetics, yet the facts of his life have proven so elusive that we still lack a comprehensive biography. Reading his work is, then, the best way of reconstructing his intellectual career, and with some limitations it provides a larger personal picture as well.

Restricted by his acute asthma and his financial situation, Lezama was housebound for extended periods. In spite of these obstacles he studied law in Havana and dedicated much of his youth to reading everything that came into his hands. Nothing went unnoticed; and many of those readings were to find their way back into his writing as 
more or less disguised rewritings. Lezama finished high school in 1928. In I930 he became a law student, but the university closed down for political reasons, and Lezama spent the following years reading Góngora, Lautréamont, Valéry, Mallarmé, and Proust. It was during those years that he started to write essays and developed his own poetics and a network of friends and writers that later constituted his closest circle. In 1956 Lezama turned down a job teaching literature at the Universidad Central de Las Villas, but a year later he read a series of five lectures at the Centro de Altos Estudios that were published as La expresión americana, a collection of essays in which Lezama expressed his own encompassing view of Spanish American culture.

The Cuban Revolution took place in I959, and in I 960 Lezama was designated director of the Department of Literature and Publications of the National Council of Culture. In $196 \mathrm{r}$ he became one of the vice presidents of the UNEAC, the Artists and Writers Union of Cuba, and in that same year his two sisters left the island. Lezama, whose sometimes elusive public persona added to the complexity of his work, experienced the separations from his sisters as traumatic experiences that, like everything with Lezama, generated more writing, in this case in the form of extensive correspondence with them. Lezama's attitude toward the Cuban Revolution is a clear example of his elusiveness toward institutional life in general. Although he held an official post, and although he wrote a poem in memory of Che Guevara, it was never clear where he stood as a supporter of the Revolution.

In 1964 Lezama's mother died. In that same year he married María Luisa Bautista, his constant companion and the person who, during the last years of his life, helped him to cope with his increasingly deteriorating health. If we were to choose two determining moments in his career, instances that could be considered turning points of his life and 
work, they would be the editing of Origenes and the publication of his first novel, Paradiso, in I 966 . This novel granted Lezama the visibility both inside and outside Cuba that he truly deserved, a kind of recognition that he did not have before its publication. Although the ten years that separated the publication of Paradiso and his death were for the most part marked by health problems, they were also a time when his work was gaining an increasingly international appreciation.

In $195^{8}$ Cintio Vitier, one of the few members of the Origenes circle still alive in Cuba, developed a massive history of Cuban poetry Lo cubano en la poesia - in which among other things he canonized Lezama's writing in an effort to make his work and Origenes organic components of Cuba's literary history. Since Lezama's death the number of works dedicated to his poetics has multiplied exponentially, as have the critical perspectives on his writings. These writers all had in common a desire to follow the multiple branching of Lezama's baroque poetics, as was the case with such canonical and esthetically diverse writers as Julio Cortázar, Severo Sarduy, Reinaldo Arenas, and Néstor Perlongher, among others, all of whom share Lezama's appreciation of the baroque imaginary.

\section{2}

Latin American literature has often been seen both inside and out of Spanish America as a dramatization of history, as a rehearsal, in content as well as form, of the cultural issues of the last five hundred years. This perspective is taken with the hope that a fresh realignment of major historical landmarks - the Spanish conquest, the wars of independence, the struggle for national organization, and so on - will provide the reader with a sense of continuity that directly or indirectly 


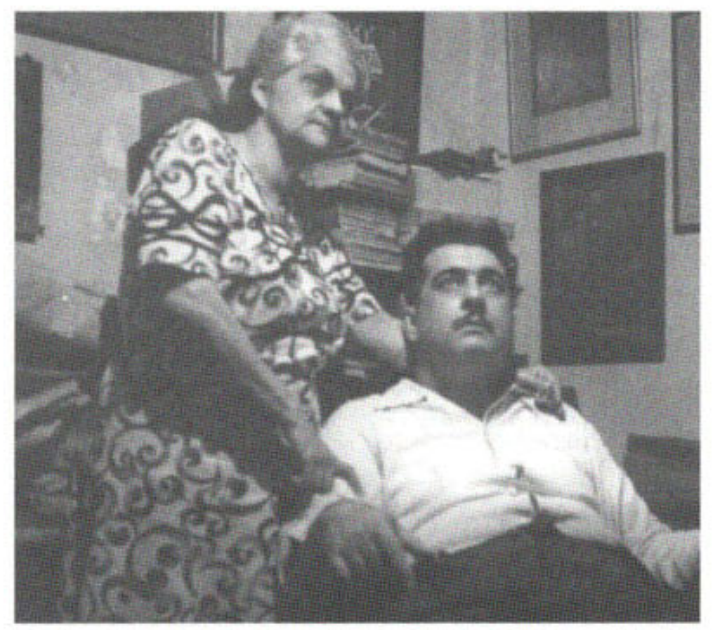

Lezama Lima with his mother, 1953.

answers the question, Who are the people alluded to in these books? Or, How do we explain the present by recovering a sense of cause and effect directly related to the past? Although for the most part very helpful, this view tends to offer a series of chronological events, an idea of progressive change and continuity that might create a sense of identity and a homogeneous sense of history. Less frequently do we find writers convinced that the most important Spanish American cultural juncture was the dynamic fusion of indigenous, African, and European influences - impossible to contain in a single definition of identity or to fix in one historical moment - which saw its first day in colonial times. Of course by definition such a vision cannot be reduced to a single frame, either by form or content, yet Cuba's present culture depends so much on issues of political independence.

It is enough to remember that while most of Spanish America declared its independence from Spain between 1810 and 1824 , Cuba was 

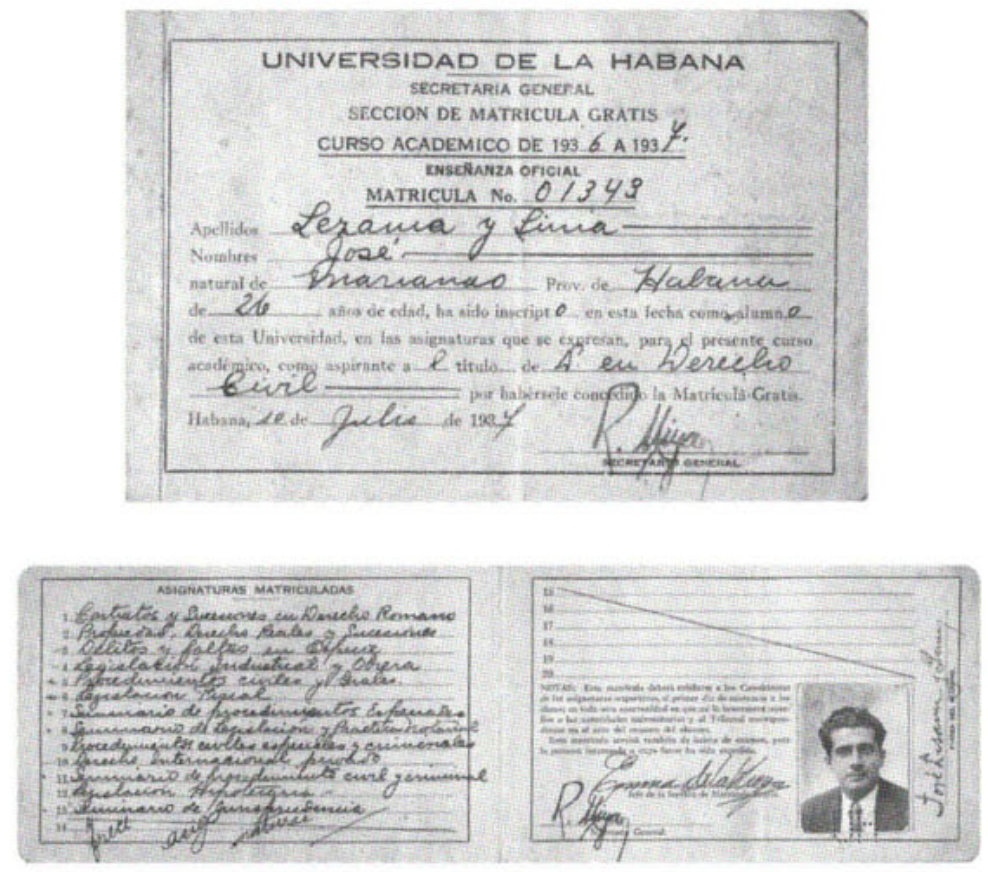

Lezama Lima's libreta universitaria, 1936. This student identification "card" is a booklet and has a number of pages, three of which are reproduced here.

still a Spanish colony as late as July I, I898, when U.S. intervention ended the Spanish regime to replace it with its own occupation. The Cuban constitution of r 901 , approved by Cubans and overwritten by the U.S. Congress that very year through the imposition of the Platt Amendment, gave the United States the power to overule political, economic, and legislative decisions made by the Cuban government. In particular article 3 of the amendment, which represented American interests in the island, giving the United States the right to intervene for "the maintenance of a government adequate for the protection of 
life, property and individual liberties," curtailed Cuban sovereignty. This new colonial establishment put conditions on the evolution of the public sphere, which was left with very little autonomy, thereby delaying the formation of a cultural industry. The struggle to establish an effective government and a true separation from the United States was a political constant through most of Lezama's life.

From very early on, when he was a law student in the early r93os, Lezama opposed the dictatorship of Gerardo Machado and later remembered with pride his participation in one of the largest student demonstrations of the time. Later he successfully navigated the fine line between his hope for the end of Fulgencio Batista's regime, which preceded the Revolution, and his equally personal ambivalence about associating his writing with institutional politics. However, in his poem "Thoughts in Havana," first published in Origenes in 1944 and later included in La fjeza (1949), we hear an echo of political concern with the Americas as a continent, at the same time that Lezama makes a direct reference to the United States' intervention through his recurrent use of English (the italics in this translation by James Irby indicate the original lines in English):

They want that death they have given us as a gift to be the source of our birth, and our obscure weaving and undoing to be remembered by the thread of the woman beset by suitors. We know that the canary and the parsley make a glory and that the first flute was made from a stolen branch.

We go through ourselves and having stopped point out the urn and the doves engraved in the chosen air.

We go through ourselves and the new surprise gives us our friends 
and the birth of a dialectic:

while two dihedrals spin and nibble each other, the water strolling through the canals of our bones carries our body toward the calm flow of the unnavigated land

Lezama calls on a common past; the verse "They want that death they have given us as a gift" could be read as a reference to the United States' intervention in Cuba's war of independence with Spain. They, the carriers of the first flute, the one "made from a stolen branch," are the Americas colonized by Europe, and both are by now inseparable from each other. While Lezama is asking for an introspectiveness that would give us friends, he also points out the existence of a dialectic rift. The poem asks us to acknowledge the "two dihedrals," each of them already forming a double angle, the North and the South, each with its own geography, looking in turn at the indigenous as well as the European components of their present, while we drift even further into the "unnavigated land," a continental reality that presumably will end the conflict between the two Americas.

As was the case with the Vietnam War for the United States, the Cuban Revolution created for Latin America a dividing line, a before and after, that changed the way Spanish American countries saw themselves in relation to each other and to the rest of the world. The Revolution not only inspired and supported many liberation movements and multiple attempts to overthrow conservative or ineffective Spanish American administrations, but it also promoted a pan-Latin American movement based on the idea of a shared language and a continental sense of cultural fusion, known in Spanish as mestizaje. Although many of the issues included in the Cuban agenda, such as land reform, nationalism, and the development of a national culture, were already present in the Mexican Revolution of Igro, the conti- 
nental, political juncture of the I 960 s was marked by the search for a political model that could overturn the cultural and political dependency of Spanish American countries; this in turn created a common ground for a shared political project, making the Cuban Revolution an attractive role model. It was not - by any means - the first incarnation of a pan-Latin American proposal. Already during the wars of independence of the early i 800 s Francisco Miranda had appealed to the British Crown, asking for support for a centralized Spanish American government with an Inca official as its head. Since then, the idea has been revisited and associated with a political model of diversity.

Lezama's own continental view of the Americas lacks any such explicit political ambition. Yet La expresión americana can at times be read as a precedent to the Revolution's model, and perhaps it even helped to negotiate his relation with the revolutionary establishment. ${ }^{1}$ But like so many events associated with Lezama's work and poetics, the official reception of his work was uneven, and he lost official backing toward the end of his life. Lezama supported the Revolution and some of its ideals of justice and sovereignty, which of course were already upheld by his beloved José Martí, one of the most prolific Cuban intellectuals of the second half of the nineteenth century. Lezama'a attitude toward homosexuality created a similar effect to that of his politics. As if walking a tightrope, Lezama seems to have taken a guarded stance on these issues, not so much to hide his position but to avoid turning himself into a target. In this respect Lezama's position was not very different from that of so many other people at the time: on the one hand, sexual preferences were for the most part kept private, and on the other homosexuality was not exactly an open topic of conversation. Although in Paradiso he makes a direct reference to the homosexuality of some of its characters, Lezama's poetry, as well as 
the majority of his writings, doesn't. His marriage to María Luisa Bautista implied some sort of arrangement between them but was probably much more than just a cover-up: it was as much a good example of the complexity of Cuba's cultural life as it was a way of protecting her from future financial problems.

The evasive quality of Lezama's writing makes it quite difficult to bury his poetics under pre-established notions of national literatures or literary schools. Literary schools are aimed at creating, for the most part, a homogeneous, more general, picture in which the exceptions to the rules remain neatly on the margins. That said, it would be very difficult to introduce a selection of Lezama's work in translation without at least attempting an outline of some of those general historical circumstances that framed his poetics, even if only to stress his efforts to redefine the boundaries of some of these schools.

By now it is understood that what we call a national literature is always more than the sum of its parts. The works and their multiple branchings are in the long run far more important than any general claim in support of a group or an esthetic circle, which tends to be the rationale of national literary politics as we know it. It is quite common for the corpus of a national literature to escape the programmatic definition of a movement. In many cases whole periods of a national literature are cannibalized and reprocessed through the formulations of new genealogies - history as an effort toward active interpretation. In their own terms those new literary movements find and redefine their poetics in dialogue with their predecessors. Very early on, Lezama's poetics moved out of a restrictive national canon; and in a very inclusive way Lezama threaded his readings throughout his writing, using 


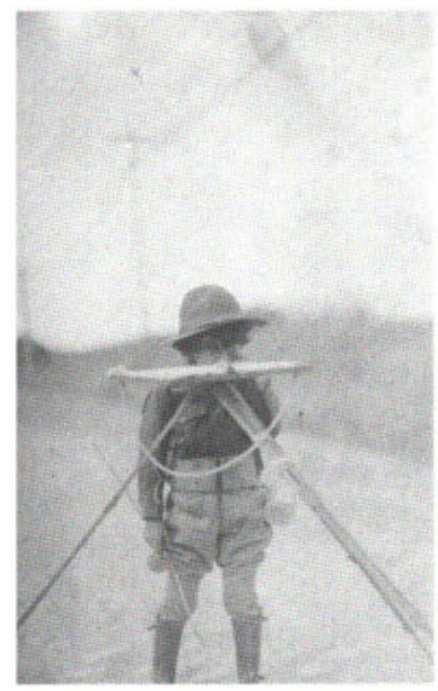

Lezama Lima as a child in an army uniform, ca. 1916.
Spanish American, French, classical, and Spanish cultural icons to draw the contours of the fusion he thought of as Latin American culture.

What a work expresses, directly or indirectly, about national literature is always the tension between our insight about the writing itself and its context and potential for addressing the present. That is why our reading and its concomitant tension, in turn, change with each new generational reading, a transformation that in this case is due to the extraordinary richness of Lezama's work and his effort to challenge predictable expectations. Lezama's insistence on a baroque esthetic has come to be perceived for what it is: an invitation to the reader to take an active part and to rewrite as he or she reads along. Therefore a critical approach to Lezama's poetry in translation needs to take into account his poetics as well as its reception.

One of Lezama's distinctive intellectual hallmarks has always been the baroque, the Spanish as well as his own Spanish American version of it. A review of at least two general characteristics of the baroque is key to understanding Lezama's poetics. One is the way in which nature seems to extend or multiply itself in cultural products, as when Lezama fuses a botanical reference with a Renaissance painting, blurring the separation between culture and the natural world in another example of inclusiveness. The other is the tendency of the baroque to bare its internal conflicts and to thrive on them instead of smoothing 
them over. It is this tension that best explains the difficulty of his work, a difficulty that both challenges and seduces the intelligence of the reader. Lezama's work essentially asks for an active reader, one willing to immerse him-or herself in the intricacies of his images.

It is this kind of inclusiveness that made Lezama gravitate toward the Spanish poet Luis de Góngora and the seventeenth-century European baroque. The Spanish baroque in particular was at once an esthetic renovation, a critique of a decadent social system, and a powerful example of the impact of Catholic theology, all concepts that are well represented in Lezama's writing. Lezama's Catholicism constitutes a pillar of his esthetic, including the iconography of his poetry and the sublime tone of his writing. Take, for example, the opening lines of the "Sonnets to the Virgin," in which nature seems to reenact God's miracles:

Deipara, bearer of God! From such deceit

To ease his bulk of care, the cuckold sire

Saw need to separate both bird from wheat

And flower from bird, not being from desire.

The more we read Lezama's work the closer we get to realizing that his apparent obscurity is an invitation to the reader to get closer to the image-making process, as when Lezama proposes in "Fifes, Epiphany, Goats":

Clarities became dark. Until then darkness has been a diabolic sloth, and clarity a contented insufficiency of the creature. Unchanged dogmas, clear darkness, which the blood in spurts and in continuity resolved, like the butterfly caressing the shepherd's forehead while he sleeps. A birth that was before and after, before and after the abysses, as if the birth of the Virgin were prior to the appearance of the abysses. Nondum eram abyssi et ego jam concepta eram. 


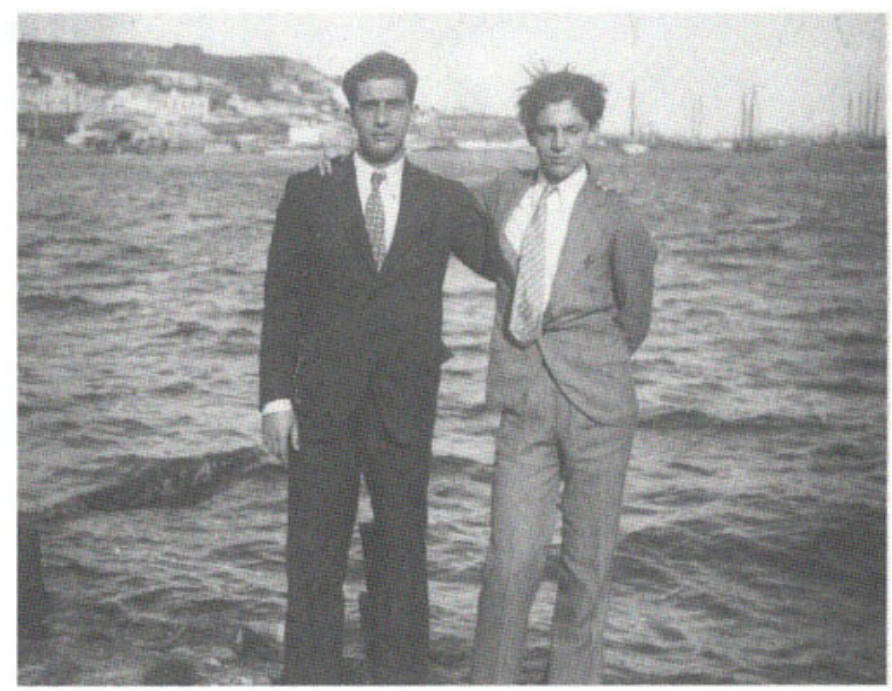

Lezama Lima and Salvador Gaztelu, r931.

At times it seems that what really attracts Lezama to Catholicism is its mystery and that what attracts him to the idea of America is its darkness - "clear darkness" - the place where mystery multiplies.

Lezama's idea of America as the ultimate site for the baroque is neither a matter of continuity with the Spanish movement nor a search for a European genealogy. For him the Spanish baroque became fully developed in America because only there did it surpass a mere effect of accumulation or excess in gaining the kind of tension Lezama believed is created by the intersection of African, indigenous, and European cultures. In the poetry of Sor Juana Inés de la Cruz, as well as in the architecture of cities like Mexico City, Cuzco (Peru), and Minas (Brazil), the Latin American engagement with the Portuguese and Spanish baroque, with its extraordinary cultural fusion, is much more than a simple extension of the peninsular movement. For 
Lezama, to write was to put into play a myriad of fragments, scraps of information, and cultural references, and his conception of the image depends on the tension that amalgamates those fragments. That cultural intersection forced Europeans, Africans, and locals to share symbolic space, creating, as I stated above, what we now call mestizaje, a vernacular culture that in Lezama's view, because of the fusion of its components, is a richer and more mature example of the baroque than is its Spanish counterpart.

In Lezama's writing difficulty is not a goal but a process, the result of his conception of the image, which - in turn - immerses the reader in a system constructed out of pure images, in many cases apparently divorced from an external referent. In fact, Lezama's complexity comes in part from his all-inclusive, sometimes encyclopedic system of quotes and references, which together with his very long and open grammatical structures contribute to his baroque style. Lezama sought and found a delicate balance between the Spanish influences that permeate, even today, everyday life in Cuba and the need for a truly Spanish American view of the arts. He rooted himself in the baroque, which he saw as the cultural bridge between the Spanish past and the American present - his favorite readings were Spanish baroque and which was also in a new and unique way the fusion of the Spanish, African, and indigenous cultures. The repercussions of his poetics outlived him by several generations, and the neo-baroque brought back some of his esthetics, as with the writings of Severo Sarduy and Néstor Perlongher, both of them active explorers of Lezama's poetics.

Lezama's baroque legacy extended itself onto the next generation through writers like Severo Sarduy, who in turn developed a formal theory of the Latin American neo-baroque. ${ }^{2}$ For Sarduy, as can be seen in his essay included in this volume, the Latin American baroque/ neo-baroque is as much a way of writing as it is a way of reading. The 
neo-baroque has been disseminated beyond the boundaries of the movement, and its traces can now be found in the work of poets as different as José Kozer (Cuba), Gerardo Deniz (Mexico), and Haroldo de Campos (Brazil); it is less a literary school than an awareness, through linguistic expansiveness and bricolage, of the multilayered reality in which we live. In retrospect the neo-baroque was another way of proposing an inventive, experimental poetic practice that did not depend on the historical avant-garde. In fact, Lezama's kept an open connection with modernismo, the movement that preceded the historical avant-garde.

4

If the baroque is one of the threads Lezama wove through his work, then Spanish American modernismo is another. Modernismo - the Spanish American movement that in its own American way carried on a dialogue with French symbolism and was therefore quite different from what is called modernism - is for the most part associated with the late nineteenth and early twentieth centuries. ${ }^{3}$ It was a movement dedicated, among other things, to building a bridge between the cultural legacy of Spain and the specificities of the Americas, in a continental sense. Though modernismo was well represented by several major poets from all over Latin America, one of them, Rubén Darío, became emblematic of the whole movement. Dario was born in Nicaragua but became, through traveling and holding various diplomatic posts, a truly continental figure and an effective promoter of the movement. That bridging came with a certain ambivalence, as can be seen in some of Darío's work, in particular "Salutación del optimista."4 Darío thought that Spanish America's bright future was based in part on the newness of the place and its 
culture, as well as on the ties that connected it with a prestigious, European tradition.

As a movement modernismo strove to make clear that, in sync with political times, its poetics was the cultural product of those new nationstates, more American in a continental sense and more interested than ever in finding a vernacular register within its own writings. Modernismo was also concerned with retaining a link with a European cultural heritage that reached all the way back to Greek and Latin classical traditions and that sifred through Spanish literature and culture. This gesture, as foundational as the new political divisions that were reshaping the geopolitical map of Latin America, was possible only insofar as those "new" countries were politically independent, or, as they would prefer to call themselves, sovereign. For Lezama, who, after all, was born almost at the very peak of modernismo and whose country enjoyed such a late independence, the movement preserved a resonance that was already in decline in other Spanish American countries. Spanish American modernismo created a transitional place where new linguistic formations, that is, the continental vernacular, could be explored as a national language. At its best, adherents to modernismo explored the possibilities of contributing to the notion of national culture, knowing that the possibilities for foundational changes would remain open for a limited number of years.

Lezama's contribution was to explore those romantic elements already present in modernismo and to expand them in conjunction with a cultural political agenda that, by Spanish American standards, was quite unusual, given the history of Cuba's frustrated independence process. Not only did Cuba lack a cultural industry in the sense of a centralized book industry and mass-produced art forms, but at that time Cuba was also navigating a space in which it was still possible to go directly from being a colony to the true newness of being sovereign. 
In comparison with other countries, Cuba achieved this transition from a Spanish colony to a revolutionary state much more directly than is the norm with the nation-state model so prevalent among most Latin American countries.

The extraordinary hybrid positioning of Lezama's poetry, his place in between modernismo and the avant-garde, was a direct and creative response to the transitional phase of the cultural institutions he was challenging. Noticing the experimental quality of his poetics is crucial because it reminds us that the meeting of explorative writing and the historical avant-garde is just one possible encounter. Experimental poetics like Lezama's have preceded the historical avant-garde and gone beyond the need for an organic connection with any given movement. It is only by taking into account Lezama's cultural context that we can start appreciating the complexity of his poetics. By responding to the cultural circumstances of his time, Lezama was able to create a new point of confluence by integrating anew all the components of vernacular culture.

Lezama Lima's work, canonical as it is, has been heavily read for his dedicated efforts to develop a foundational view of Latin American culture, a preoccupation that follows from his ever-present concern with origins. In this sense Lezama puts forward his own interest by exposing an all-encompassing project, while at the same time feeding a foundational equation: cultural fusion as continental identity. Any historical approach to his work will therefore need to take into account the circumstances and the cultural forces that made Lezama's work as well as Origenes - the influential journal he edited from 1944 to 1956 - possible.

The development of his poetics, and, by extension, the work of the artists associated with his work, was directly linked to four literary journals, all edited or co-edited by Lezama. The first of those mag- 
azines, Verbum, published only three issues, all of them in 1937 - the same year that Lezama published "Muerte de Narciso," his first major poem. The second magazine, Espuela de plata, consisted of six issues published between 1939 and 194I. A third one, produced in collaboration with Angel Gaztelu, was called Nadie Parecía and managed to publish its tenth issue in 1944. The writers' use of the journal as the preferred publishing medium reflects a scarcity of distribution means. In fact, the magazine format proved to be the best way of establishing a public space and of extending a writer's social and intellectual circle.

It was also in 1944 that Origenes appeared for the first time, and it lasted

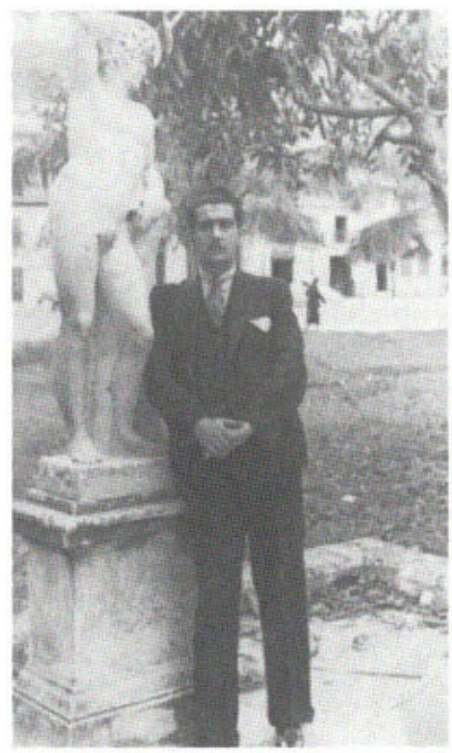

Lezama Lima leaning against a statue of Apollo in front of the amphitheater, 1935 . until 1956. Next Lezama published $\mathrm{La}$ expresión americana, his most programmatic book of essays. ${ }^{5} \mathrm{He}$ co-edited Orígenes with the critic José Rodríguez Feo and relied on contributions from a vast circle of Cuban intellectuals and artists: writers Angel Gaztelu, Virgilio Piñera, Fina García Marruz, Lorenzo García Vega, Justo Rodríguez Santo, and Eliseo Diego; painters Alfredo Lozano and René Portocarrero; and musicians like José Ardévol and Julián Orbón. For Lezama what best defined the dynamics of the group was friendship, understood as an ongoing dialogue and as reading one another's work, beyond the actual making of the magazine. This particular quality, which could easily be overlooked, helps us to understand that the relevance of Origenes rests on the fact that so 


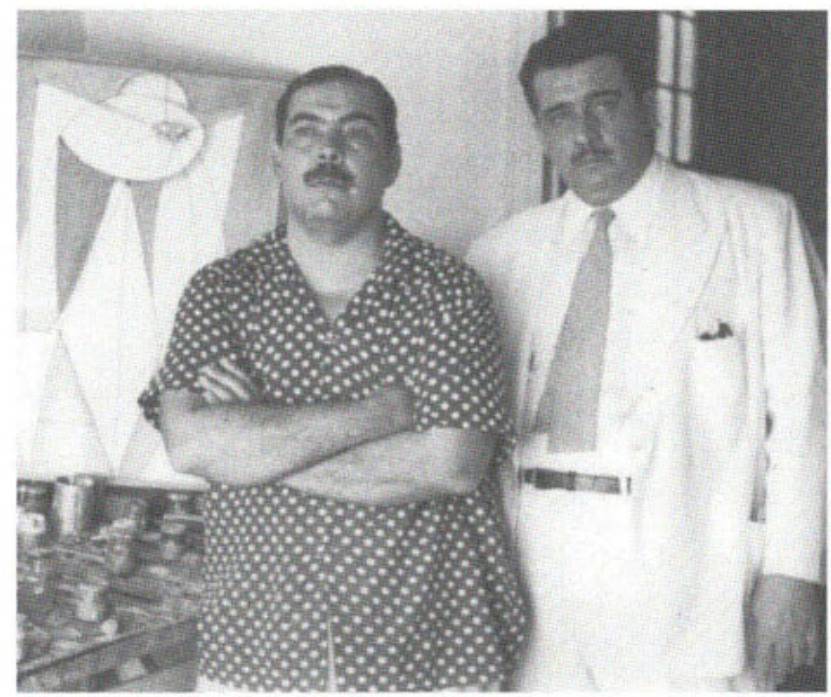

The painter René Portocarrero, who was also a member of Orígenes, and Lezama Lima, 1953.

much work was done with a fair amount of autonomy, with very inclusive editorial criteria, free from a rigid agenda, and always within the dynamics of a social encounter. The center of all intellectual exchange was closer to the coffeehouse or to Lezama's home than it was to a magazine office. Again, the social tissue, the sociability of everyday Cuba, is key to assessing the impact and success of Origenes.

Because of the historical proximity of Lezama's work and his impact on the generation that succeeded him, his poetry was perceived as the bridge in literary Cuba between the first and second half of the twentieth century. In Spanish America this transition is much more than a chronological passage through time; it also implicitly refers to the transition from political independence to full-fledged nation- 


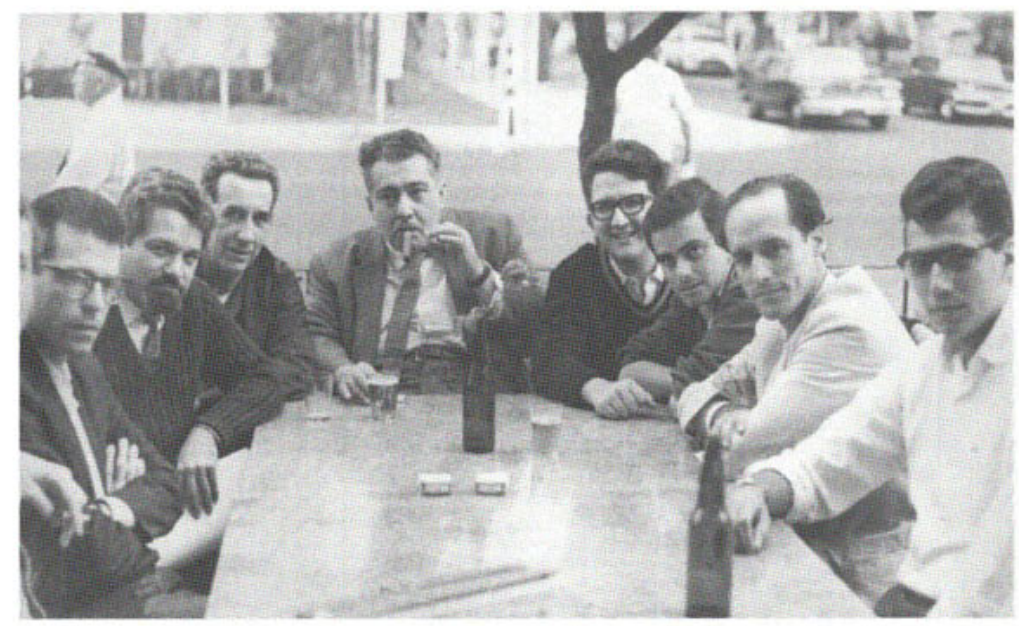

A group at a cafe on Calle 23 and F, 1966. From left to right: Antón Arufat, Pablo Armando Fernández, Mariano Rodríguez, Lezama Lima, Heberto Padilla, Sigifredo Alvarez Conesa, Roberto Fernández Retamar, and Victor Casau.

state status. The avant-garde movements so present during the first half of the century were as deeply concerned with formal renovation as they were interested in reflecting on the present. Orígenes was interested in both, but Lezama would also make connections to other historical movements, rendering the journal a much more inclusive publication.

This perception - of Orígenes as an open, less programmatic journal - was framed by the fact that in the r 940 os Lezama, as editor of Origenes, engaged in a controversy with Jorge Mañach, the former editor of another Cuban literary magazine, the Revista de Avance, which stood for an avant-garde esthetics, one which equated progress with modernity. In retrospect, the exchange between these two editors is 
critical in understanding Lezama's poetics in a much wider context than that of the exchange itself. ${ }^{6}$ The discussion, begun by Mañach through an open letter published in 1949 , constituted a response to $L a$ fijeza, Lezama's book of poems from that same year. Mañach begins his letter by stating that Origenes owes an intellectual debt to the Revista de Avance, because in his eyes the experimental character of Lezama's literary circle was simply a variation of his own avant-garde position. Lezama's response to Mañach's indictment was to create his own list of authorities, while asserting his own journal's merits in attracting a prestigious series of contributors. The list included the names of the writers published in Origenes, such as Saint-John Perse, George Santayana, T. S. Eliot, and others whom, although not always included in the magazine, Lezama thought of as his group's equals: Alfonso Reyes in Mexico, and Ezequiel Martínez Estrada and Jorge Luis Borges in Argentina, all writers more concerned with rescuing tradition than with breaking away from it. If we compare the poetics of Lezama to those of Vicente Huidobro, the Chilean poet who founded creacionismo, one of the most visible avant-garde poetry movements in Spanish America, we will find that while creacionismo was trying very hard to break away from literary canons, Lezama was trying not only to include them all but in effect to expand them beyond the more programmatic avant-garde that in Mañach's view was associated with novelty and rupture from tradition.

Although the discussion between Lezama and Mañach offers us a sharper view of the positions at stake at a time when Cubans were openly discussing the possibilities of modernity, by focusing entirely on the opposition between Avance and Origenes one runs the risk of distorting the picture by equating Avance with the only experimental agenda, while leaving Origenes either in a more traditional position or in an indefinable critical space. In fact, recent critical readings of the 


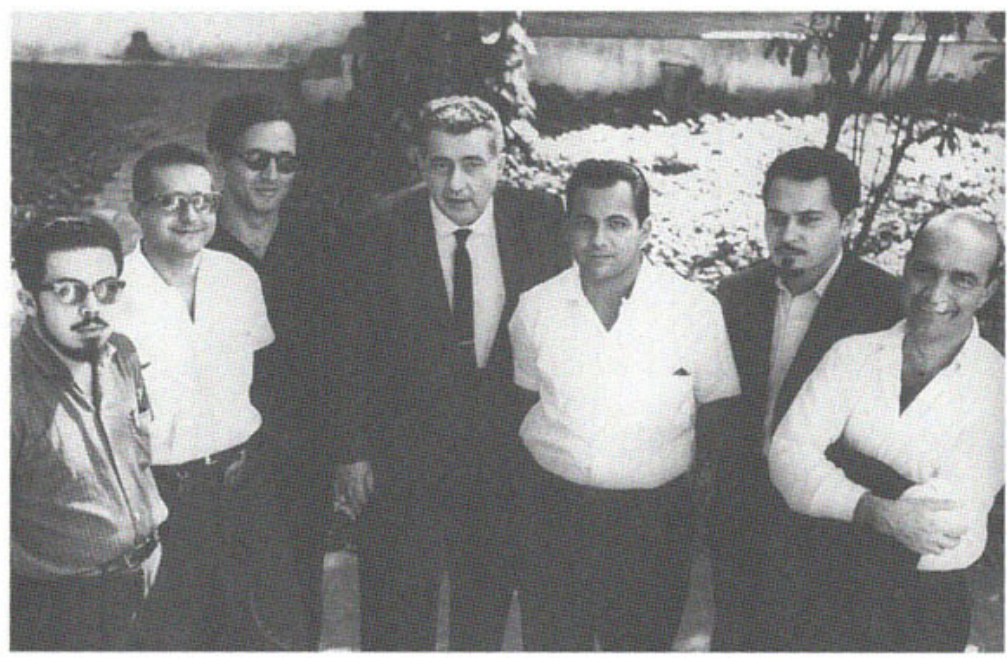

From left to right: Manuel Díaz Martínez, Roberto Branley, César López, Lezama Lima, Armando Alvarez Bravo, Fayad Jamís, and Onelio Jorge Cardoso, 1966.

work of some other Orígenes writers, such as Reinaldo Laddaga's work on Virgilio Piñera, José Antonio Ponte's essay on Lorenzo García Vega, and Duanel Díaz Infante's "Mañach or the Republic," successfully place Orígenes in a larger picture and offer a perspective from which to view both these magazines as part of the same tissue, while giving back to Lezama a much-deserved complexity. Although Virgilio Piñera was a prolific writer of poetry, short stories, and plays, his work has only recently started to be published again outside Cuba. Yet translations of his books into English are still rare. Like Piñera, García Vega was also part of Orígenes, and his extraordinary memoir of the group, Los años de Orígenes, published in Spanish in 1979 and already many years out of print, is indispensable in acquiring a deeper understanding of how so many different voices could be part of the 


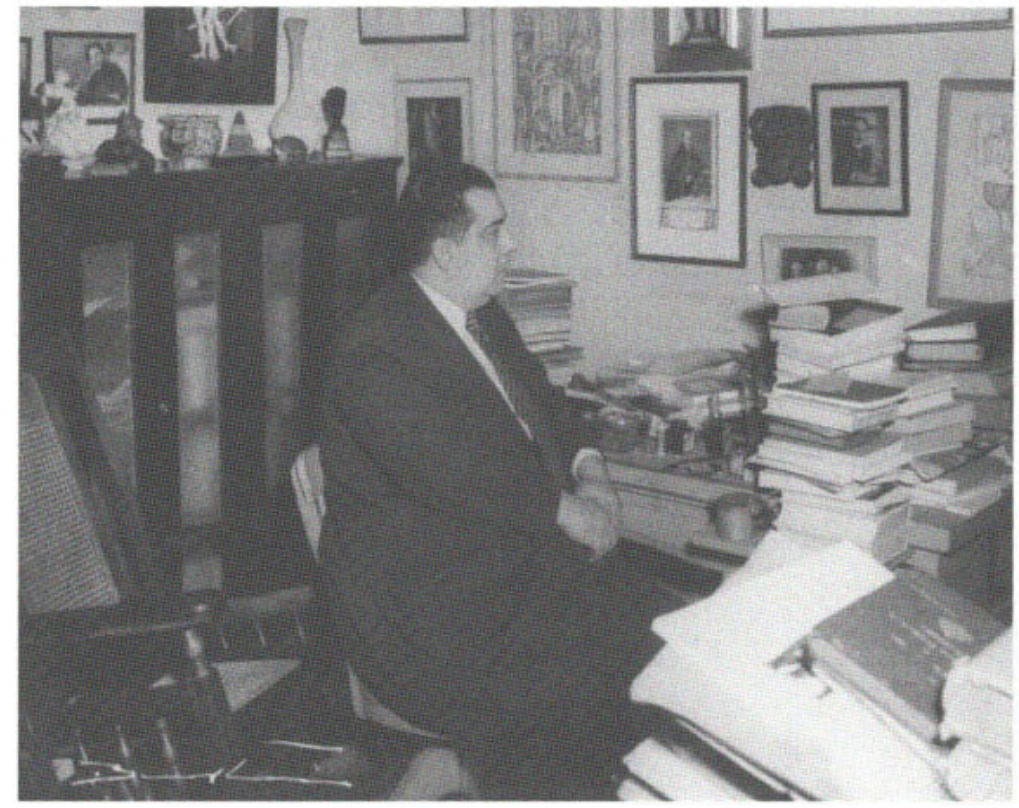

Lezama Lima in his study, 1960.

same magazine. Piñera and García Vega have remained for the most part invisible and in the good company, virtual as well as real, of other writers overshadowed by the Boom: Witold Gombrowicz, Felisberto Hernández, José Bianco, and Juan Rodolfo Wilcock, among others. ${ }^{7}$

Orígenes, not only the magazine but its circle of writers, would try to supply a unifying cultural model, thereby creating a sense of national identity - what Lezama likes to call in his "Colloquium with Juan Ramón Jiménez" a pure definition of poetry and, by extension, of culture, which I believe in Lezama's case is interchangeable with his poetics. For Lezama, a cultural blending is neither an ideal nor a goal, but a reality. Interestingly, his model of purity is anything but trans- 
parent and tends to set in motion an almost out-of-control mechanism of encyclopedic references that provide the content for his baroque sensibility. This attempt to create an all-encompassing Cuban poetics through Origenes is paradoxical, given that the project did not follow an institutional model. This gap, between his vision of a unified, fusion model and the state of cultural institutions at the time, created the sense of displacement that even today we encounter every time we try to place Lezama's work in a larger historical frame. In this way Lezama's cultural project was several decades ahead of its time, and this fact in turn helps us to understand the late, but very positive, reception of his work by some of writers of the Boom, during the first years of the Revolution.

5

In spite of his work as a poet and editor Lezama was not very well known outside his country until the publication in 1967 of his first novel, Paradiso, which was received in the context of the international phenomenon known as the Latin American Boom. The young writers of the Boom - an ideological stance and a confluence of esthetic affinities more than an organic movement - were eager to distance themselves from the realism of the I930s and I940s, while preserving an interest in the social and the political. The core writers of the Boom - Gabriel García Márquez, Carlos Fuentes, Mario Vargas Llosa, and Julio Cortázar - who favored a monumentalist esthetic, which they thought capable of expressing the cultural complexity of Spanish America, saw in Lezama one of the greatest founding figures of their own poetics. Cortázar's efforts to promote Paradiso included one of the first and most influential critical articles ever dedicated to Lezama's work: “To Reach Lezama Lima," from i 967 , included in this 
volume. Cortázar not only promoted Lezama's writing, but he also took upon himself the never-ending task of proofreading Paradiso. At least two aspects of Lezama's writing supported this genealogical, although retroactive, designation as a precursor to the Boom. For some of the Boom writers, Julio Cortázar and José Donoso among others, Lezama's work reformulated the Spanish baroque as a defining characteristic of Latin American identity, while integrating European, African, and indigenous colonial realities. In itself this reappropriation of colonial influence was a masterpiece of cultural fusion and offered a possible closure to the long-lasting discussion about the boundaries of Latin American culture, as well as to the formal and the contentoriented definition of those limits. ${ }^{8}$ As part of his cosmogony, Lezama put forward a pan-Latin Americanism of sorts that was very much in tune with the dominant political agenda of the 1960 and 1970 , creating an extremely fertile climate for the reception of his work. A description of Lezama's unique situation as a writer, then, could start with the fact that in spite of his long, prolific life as a writer and cultural broker in his own right, Lezama's work was disseminated outside Cuba through, and to some extent was appropriated by, the eyes of the next generation, the Boom and its readers. ${ }^{9}$ It is paradoxical that for many writers associated with the Boom one of the most obvious amalgamating factors of their generation was, without any doubt, the Cuban Revolution, which in turn would change forever the cultural environment in which Lezama established himself as a writer.

The association of Lezama's work with the Boom created a certain distortion in the reception of his work: while the Boom consisted almost exclusively of a group of novelists, at that time Lezama had published only one novel - Paradiso — and a few short stories, while the majority of his work consisted of an important collection of poetry and essays on poetics. Since the critical excitement generated by the Boom 


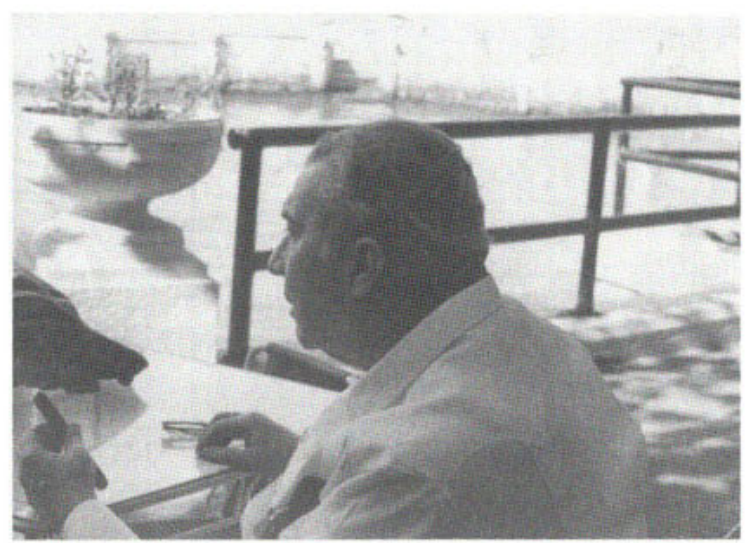

Lezama Lima, 1975.

supported the idea of the novel as the ultimate genre, Lezama's poetry is often viewed as the path leading to his novels, the above-mentioned Paradiso and the unfinished and posthumous Oppiano Licario. Today, almost half a century after the first publications associated with the Boom, it is easier to look at Lezama's fiction, poetry, and essays as simultaneous, rather than as a precursor to exploring the same poetics.

If the continental projection of the Boom and the controversial exchange with Mañach over the avant-garde are clear ports of entry to Lezama's poetics, I would like to suggest another approach, that of examining one of his earliest essays. Lezama's interest in literary history was particularly evident in his efforts to formulate a theory of literature that would integrate Spanish and Cuban literary traditions into the same poetics. From very early on in his career this fusion can be seen, more indirectly in some of his first essays - "The Secret of Garcilaso" and "Sierpe of Don Luis de Góngora" - and more clearly in "Colloquium with Juan Ramón Jiménez" from 1937. 
Lezama's "Colloquium with Juan Ramón Jiménez" constitutes one of the most spectacular acts of Euro-American ventriloquism of the first half of the century. The anecdote is simple. A famous Spanish poet, Juan Ramón Jiménez, visits Cuba and is courted by local writers. Lezama writes an entire dialogue between himself and Jiménez, writing both voices in a style that is so unmistakably his that Jiménez felt the need to write a short disclaimer published as an additon to the exchange: "I have preferred to accept everything my friend attributes to me and make it mine as much as possible than to question with a firm no as it is sometimes necessary to do with the attributed writings of others and easygoing talkers." ${ }^{10}$ Lezama fulfills two goals. On the one hand, he pays tribute to an admired poet, and on the other he takes advantage of his fictional interlocutor in order "to talk" about Cuba with the impersonated distance of a foreigner. Earlier Lezama states "The crystal serpent is already on other skin and it takes us time to accept that the older skin is already paper, that paper falls with the elegance of a wrinkled leaf." 1

In his introduction to the essay, Lezama suggests that the skin of the serpent is left behind, but the arrow that was covered by that skin moves on. It seems that at the time of his visit to Cuba Jiménez was that arrow, in a different skin. He has mutated while retaining the core, with that which does not change - that is, himself - serving as the perfect example of what he will be asked to discuss. Can Cuba be an island and still be Spanish? Is it just a change of skin? Does the place retain the arrow, or does it move beyond containment?

We now see that the main theme of this fictional, almost ironic, exchange arises from the question, Is Cuba an example of insularity? Or, more explicitly, Is it valid to speak of Cuban culture in terms of its distance from the European continent? ${ }^{12}$ At one point, Jiménez, in the ventriloquist voice of Lezama, poses a question about the true consti- 


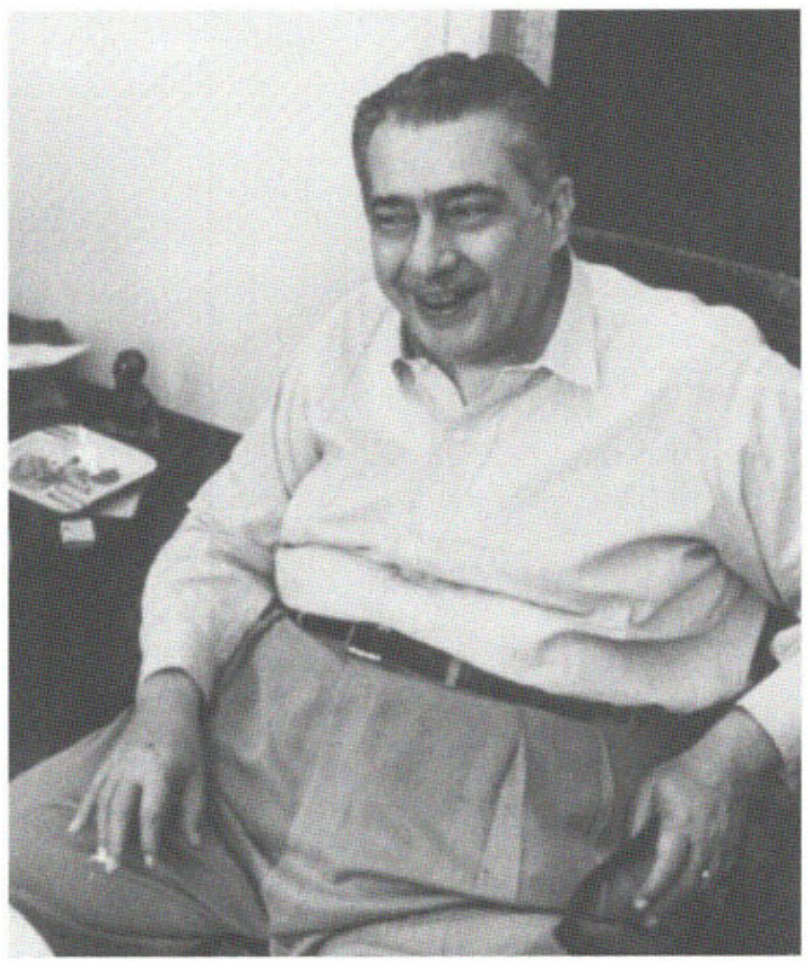

Lezama Lima at his house, ca. 1970.

tution of an insular poetry. At the same time, "he" - Lezama through Jiménez - says, "These days I have heard in Havana a lecture on racial fusion, a fusion that would necessarily create a mestizo poetic expression. I am interested in knowing if the search for a distinctive insular sensibility is not the opposite of this mestizo expression."

To this, the "true" Lezama answers that artistic mestizaje implies an unacceptable eclecticism, forcing poetry to choose between an absolute love and a well-defined rancor, with nothing in between. 
Furthermore, for Lezama, an insular sensibility is not in conflict with a universalistic solution. More important is for mestizo culture to imply a dissociation from a "feudal sensibility" and therefore a distancing from the kind of universalistic purity that Lezama sees as the destiny of every great national culture. ${ }^{13}$

In some ways this is the same cultural model that was dominant among the modernistas: the search for a form that would be their own not only because of its well-defined lines, but also because it would carry the original imprint of a new continent. If successful, this new form should attract a continental recognition.

The concept of a pan-Latin Americanism, as an all-encompassing cultural model, was not a novelty in Lezama's time. On the contrary, it is a cyclical cultural model that seems so appealing because it is almost a "natural" by-product of sharing the "same" language. Yet by the beginning of the twentieth century, that door was almost closed, and the boundaries that divided Spanish American countries had become sharper as a consequence of the nation-state formation. Lezama's work stems from his idea that the baroque quality of its images shares, in a sense, that continental quality that he thought of as a regained familiarity with the core of Latin American culture.

More than in his fiction or his essays it is in his poetry where Lezama's proposed tension between what we as readers are able to recognize as familiar and what we are out to discover achieves the highest intensity. In "Resistance" (I949), one of the prose poems included in this collection, Lezama, in ventriloquist fashion, explains what he does while he does it. The "resistance" of the title is already twofold: what we experience as readers while confronted with the text and what we should look for to reach an insight.

What morphology allows, the realization of an epoch in a style, is very scant in comparison to the eternal resistance of what is not permissible. 
Potency is merely the permission granted. Method: not even intuition, not even what Duns Scotus called confused abstract knowledge, reason in disarray. Method: not even creative vision, since total resistance prevents the organizations of the subject[... ] Then ... On this night, at the beginning of it, they saw fall from the sky a marvelous branch of fire into the sea, at a distance from them of four or five leagues (Journal of Voyage, 15 September 1492). Let us not fall into the idea of paradise regained, for the men who came packed into a ship moving within a resistance could see a branch of fire fall into the sea because they felt the history of many in a single vision. Those are the times of salvation and their sign is a fiery resistance.

Our knowledge of the "permissible" is minimal in comparison to what we don't know and therefore should not be taken as a means of arriving at a safe harbor, but rather as an incentive to constant movement, even at the risk of dispersing and fragmenting that potency. For Lezama it carries more weight to propel the reader into his or her own series of associations than to reach a unique interpretation, a definitive meaning. The quote incorporated in the poem, indicated by the italics, is from Christopher Columbus's journal, the implication being that the founding of America was, for all parties involved, the product of multiple resistance. In Lezama's poetics resistance and difficulty are not merely preconceived by the writer but the result of a praxis of seeing and recognizing the poem as the tension between the images we as readers are acquainted with and the ones we are about to discover.

With the exception of Cintio Vitier, the other members of the Orígenes circle - Rodríguez Feo, Lorenzo García Vega, Virgilio Piñera, and René Portocarrero, among others - were less interested than Lezama in the creation of an autonomous critical system. For Lezama, the complex uniqueness of his poetics demanded a critical development but always as an extension of writing as a whole. At times this unique- 


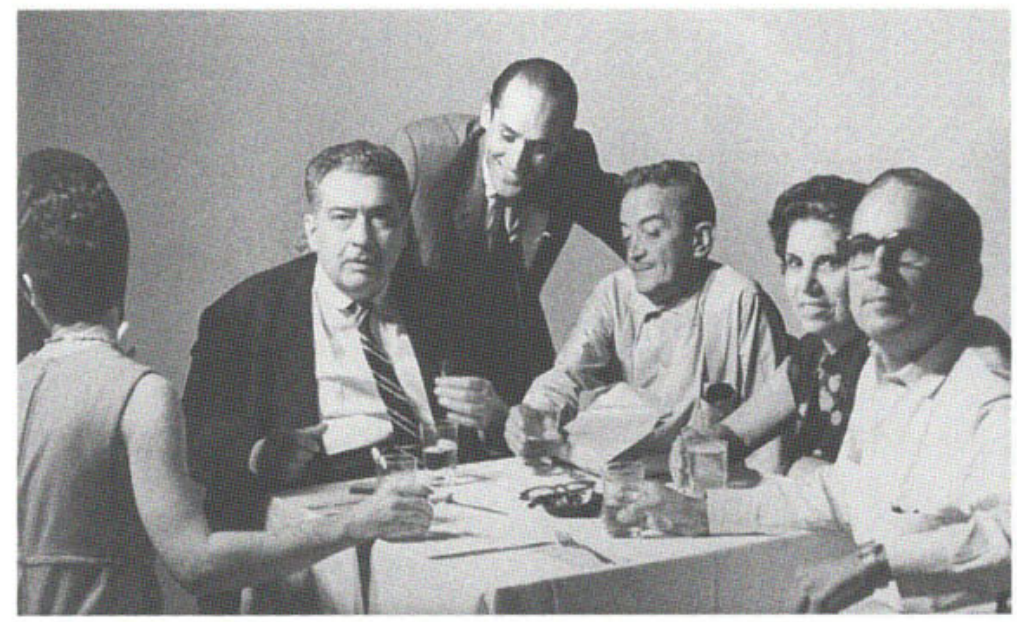

From left to right: Chiqui (back to camera), Lezama Lima, Roberto Fernández Retamar, José Bianco, María Luisa Bautista, and José Rodríguez Feo, 1968.

ness would create an equally distinctive hermeneutics and generate a dedicated body of criticism pointing to the singularity of Lezama's writing as inseparable from his literary persona. In this sense, Lezama resembles the American poet Charles Olson. Both were concerned with a foundational poetics capable of accounting for the originality of the Americas, and both in their own ways thought of continental migration in mythopoetic terms. Lezama, like Olson, was highly aware of the importance of place and he could say, like Maximus:

I come back to the geography of it

An American

is a complex of occasions, themselves a geometry of spatial nature. ${ }^{14}$ 


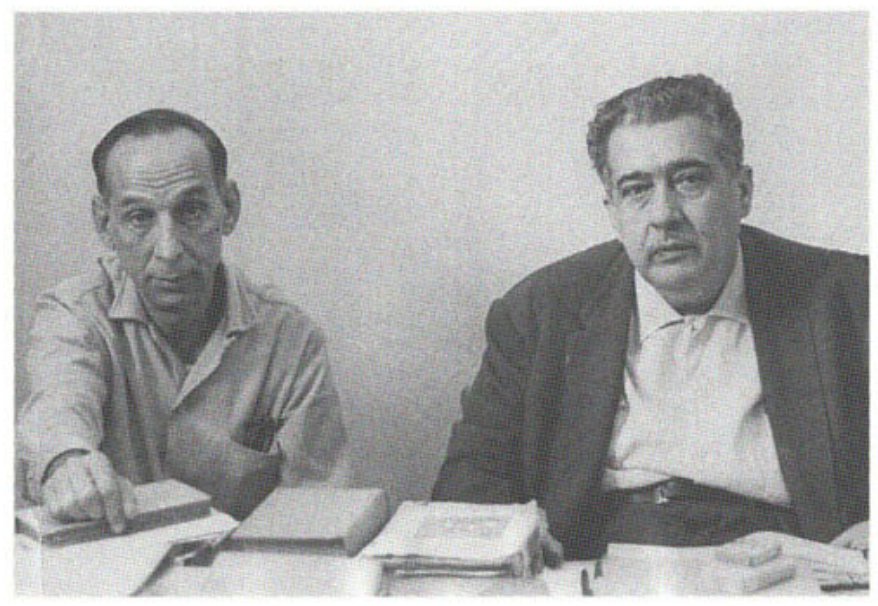

Virgilio Piñera and Lezama Lima, 1968.

Lezama's Havana in 1910 was quite a different place from Olson's Worcester, Massachusetts - except perhaps for the fact that both cities are often defined by their connection to a colonial past. The differences prevailed, and Lezama's interest in American poetry never included Olson or the Black Mountain writers with whom Olson was associated. Nonetheless, both were very much aware not only of their American condition but also of how much their America lay somewhere in between Europe and the indigenous cultures of this "new geography." They shared the awareness that if European influences were somehow a given, the same could not be said of the impact of the indigenous cultures on the present Americas, that to recover what colonial times have covered up so neatly would constitute an intellectual challenge. Lezama saw it in the baroque quality of indigenous religious art, Olson looked for it in Mayan culture, and they both un- 
derstood like few others that the newness of modernity was already embedded in America.

For the process of soliciting contributions from U.S. writers, Origenes relied on Rodríguez Feo, the wealthy traveling journal editor. Lezama and Rodríguez Feo were very interested in T.S. Eliot and Wallace Stevens. Lezama felt an affinity with Eliot and Stevens both, being as they were concerned with the metaphysics of representation and the re-elaboration of European heritage. Like them, Lezama wanted to reinterpret and, to some extent, reinvent cultural ties with Europe. Lezama also shared with Eliot a rooted interest in Catholicism, an interest that shows more or less elusively in a good number of the poems selected for this anthology. But unlike Eliot or Stevens, he brought things European into his own idea of America, as he does when fusing the Spanish baroque and Afro-American tradition; and he merges them without the special effects of magic realism. ${ }^{15}$ Lezama does simultaneously what very few others have done: he reviews the past with a strong sense of proximity, making tradition inseparable from the most alive aspects of the present. It is not a matter of nostalgia, as it is in the works of Eliot or Stevens, but of a baroque vibrancy that places him so close to Olson and Maximus. Ultimately Lezama and Olson shared a sense of fascination for the Americas as the ultimate, limitless place for intellectual self-discovery and invention.

6

Nothing really prepares us for Lezama's expansiveness, and therefore the work of translating these texts is as extraordinary as the original poems themselves. James Irby's and some of Roberto Tejada's translations were first published in Sulfur, while others were especially requested for this volume. Four of the seven translators included in this 
anthology worked on poems from different stages of Lezama's career, and they brought different assumptions about his poetry to the task. James Irby and Roberto Tejada managed to create a transparency that brings us right into the middle of the poem, creating the kind of enticement that we find in the Spanish texts. Gary Racz translated poems from one of the most baroque periods in Lezama's writing career, and his approach was to masterfully re-create the turns and obstacles of the original. Finally, Nathaniel Tarn's version of "An Obscure Meadow Lures Me" has the unique sound of twentiethcentury American poetry, and, like the other translations, serves as an important reminder that the interest in Lezama's poetry has been very much present for a long time. The multiple translation strategies, as well as the variety of selections chosen for this volume, are meant to compose a complex picture offering the most precise possible view of the foreground with the best background definition. The creative and sustained work of the various translators involved in this project is one of the best keys we have today to Lezama's poetry. Since this is the first book-length anthology of José Lezama Lima's poetry in English, I have included poems from each of his books to show how Lezama's poetry slowly moves from the expansiveness of "Insular Night: Invisible Gardens" from Enemigo Rumor (I94I) to the almost haikulike quality of certain stanzas in "They Slip through the Night" from Fragments Drawn by Charm (1977).

Lezama's poetics has remained faithful to its principles, almost as if time has led to a certain degree of compression, but now the images have also taken on an element of lightness. The images are still there, though in "They Slip through the Night" it is possible to see through them. The contours bear Lezama's style, but the center is truly full of unobtrusive specificity, as if proving that a concrete image can move further away from its referent, bringing us closer and closer to the re- 


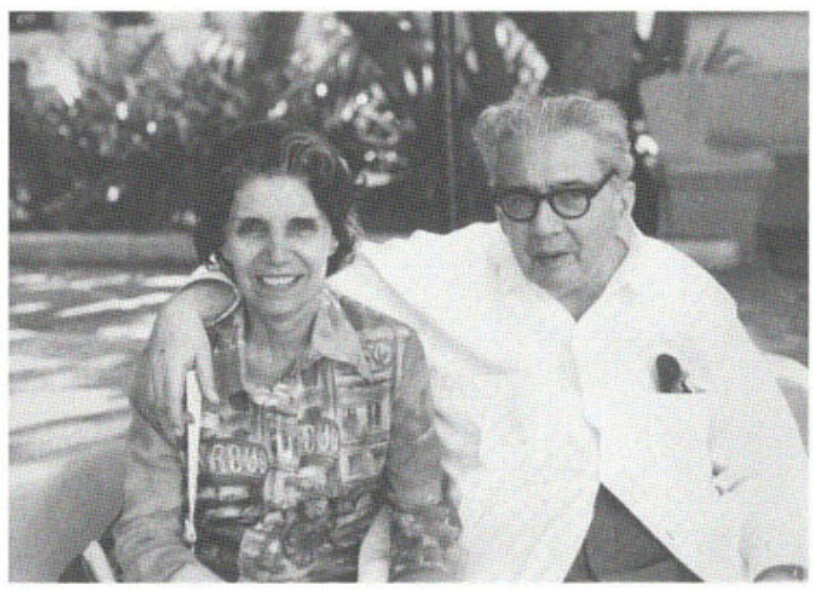

María Luisa and Lezama Lima, in one of the last pictures of the poet, 1975 .

ality of language. At the same time Lezama's poetics are important to us because the issues that inspire his writing remain urgent, as we find ourselves asking, once again, about the limits of national literatures and cultures. His poetic plays on the tension between being inside and outside national boundaries and between formal constraints and expansive content, and on the sometimes blurry distinctions between the author and his writing, open up a dialogue with other works that we now know reaches all the way to the present.

Ernesto Livon-Grosman April 2004 


\section{NOTES}

1 Lezama was not alone in his search for an all-encompassing view of the Americas. Mexican Ulysses, an Autobiography by José Vasconcelos, In the American Grain by William Carlos Williams, and The Americas and Civilization by Darcy Ribeiro are some examples of writings that reflect the sentiments found in Lezama's essay.

2 Sarduy's seminal essay "El barroco y el neobarroco," originally published in 1972, remains one of the clearest and most systematic on the subject (in Obra completa, 1999).

3 I use the term modernismo in Spanish to differentiate it from modernism in English. The former refers to a Spanish American literary movement that took place at the end of the nineteenth and the beginning of the twentieth century and was closely associated with French symbolism, while the latter is a term that is more broadly associated with post-symbolism and the historical avant-garde. In Latin America modernismo was chronologically followed by the historical avant-garde, and although some writers were associated with both movements at different points of their careers, it is fair to say that those involved in the avant-garde bore a strong desire to break away from modernismo.

4 Rubén Dario's 1905 "Salutación del optimista" is included in Cantos de vida y esperanza (in Poesía, 1977). For a long and comprehensive commentary on this poem and its ideological echoes, see Gerard Atching's The Politics of Spanish American Modernismo.

5 Lezama published forty issues of Origenes, the last one in 1956, but it is not unusual to give 1957 as the last year of the magazine because, as Lezama himself stated in a conversation with José Prats Sariol and quoted in "La revista Origenes," "When we handed in the fortieth issue we weren't sure of the end." So perhaps we can say that 1957 was the year when Origenes stopped functioning as an entity.

6 I am indebted to Emilio Bejel and his book José Lezama Lima: Poeta de la imagen (1994) for an insightful description of the exchange between Lezama and Mañach. A longer analysis of Mañach's poetics and intellectual biography can be found in "Mañach o la República" by Duanel Díaz Infante. This essay, to be published in Havana in 2004, was kindly lent to me in advance by the author shortly before I finished this introduction. 
7 Witold Gombrowicz, who was stranded in Argentina during World War II with no job and very little knowledge of Spanish, nonetheless became one of the main influences on Argentine fiction writers who came after the Boom. While living in Buenos Aires he translated Ferdidurke from Polish into Spanish with the help of Virgilio Piñera, who was also living in Argentina at the time. The connection was more than circumstantial; they both shared an outsider's point of view that is embedded in their poetics.

8 Lezama developed his theory in La expresion americana, the five lectures he delivered in the Centro de Altos Estudios de la Habana in 1957.

9 One of the earliest and most daring assessments of Lezama's writing can be found in Julio Cortázar's article "To Reach Lezama Lima," included in Around the Day in Eighty Worlds (and this volume). During the first years of the Revolution this new valorization of Lezama's writing came mostly from outside Cuba. To better appreciate the complexity of his reception during those years it is worth looking at the criticism published in Lunes de Revolución, one the most reputable newspapers of those first revolutionary years.

10 "He preferido recoger todo lo que mi amigo me adjudica y hacerlo mío en lo posible, a protestarlo con un no firme, como es necesario hacer a veces con el supuesto escrito ajeno de otros y felices dialogadores" (Obras completas, 45).

11 "La serpiente de cristal está ya sobre otra piel y nosotros tardamos en convencernos de que la piel anterior es ya un papel, de que el papel cae con la elegancia con que se frunce la hoja" (Obras completas, 44).

12 The idea of insularity as a defining character of national literature can be found in the writings of other Lezama contemporaries from the Americas. Interestingly enough, only three years before Lezama's dialogue with Ramón Jiménez, Gertrude Stein delivered her Lectures in America. In one of them, "What is English Literature," she builds a case for the specificity of American literature by contrasting it to the particulars of writing in England: "On a continent even in small countries on a continent the daily life is of course a daily life but it is not held in within as it is on an island and that makes an enormous difference, and $I$ am quite certain that even if you do not see it as the same anybody does see that this if it is the truth is the truth" (18). Lezama was far less inclined to claim this insular specificity and preferred instead to put Cuba on common ground with the rest of America. 
13 My first encounter with the text was in Benigno Sánchez-Eppler's essay on Juan Ramón Jiménez and Lezama. His observations have helped me to shape my own ideas about Lezama's concern with the possibilities of an ongoing connection between Cuba and Spain.

14 Maximus to Gloucester, Letter 27 [withheld] (in The Maximus Poems, i 84).

15 Lezama did not become associated with magic realism, although Alejo Carpentier, another baroque Cuban and a very influential novelist, was both a contemporary of Lezama and one of the founding fathers of that school. 
